\title{
Komparasi Metode Koreksi Spektrum NIRS (De-Trending dan Derivatif ke-2) untuk Penentuan Kadar Air Bubuk Biji kakao
}

(The Comparison of Spectrum NIRS Correction Method (De-Trending and 2ndDerivatives)

to Determine the Water Content of Cocoa Powder)

Masdar*, Zulfahrizal, Agus A. Munawar

Program Studi Teknik Pertanian, Fakultas Pertanian, Universitas Syiah Kuala

\begin{abstract}
Abstrak.
Rendahnya pengawasan mutu kakao menyebabkan harga jual di pasar dunia menurun akibat kurangnya pengawasan kadar air. Salah satu metode yang tepat dan cepat dalam penentuan kadar air adalah menggunakan atau Near Infrared Reflectance Spectroscopy (NIRS). Tujuan penelitian adalah melihat kemampuan NIRS dalam memprediksi kadar air bubuk biji kakao dengan menggunakan metode Partial Least Squares (PLS) serta membandingkan dua metode pretreatment De-trending dan Derivatif $k e$-2.Alat yang digunakan FT-IR IPTEK T-1516, dan pengolahan data dengan unscrambler software ${ }^{\circledR}$ $X$ version 10. Hasil penelitian menunjukkan NIRS mampu menduga kadar air dalam jumlah 10 gram dengan selang kadar air 7.42 - $11.09 \%$ menggunakan PLS secara non pretreatment maupun pretreatment. Panjang gelombang relevan dalam menduga kadar air bubuk biji kakao adalah $1400-1450$ $\mathrm{nm}$ dan 1800-1950 nm. Peningkatkan kinerja PLS yang paling bagus menggunakan pretreatment derivative ke-2.
\end{abstract}

Kata kunci :Kadar Air, Bubuk Biji Kakao, Pretreatment, NIRS

\begin{abstract}
.
The lowest quality of cocoa supervision cause the selling price descrease due to the lack of supervision on the water content. One of the exact method in determining the water content is Near Infrared Reflectance Spectroscopy (NIRS). The purpose of this study is to know the capability of NIRS in order to predict the water content of cocoa by using Partial Least Squares (PLS) method then compared the two pretreatment methods namely De-trending and second Derivative. The instrument used was FT-IR IPTEK T-1516, and the spectra data were analyzed by using unscrambler software ${ }^{\circledR} \mathrm{X}$ version 10. The results showed that NIRS can be used to predict the water content in amount 10 grams in a range of water content 7:42 to 11:09\% by using PLS non pretreatment and vice versa. The relevantwavelengthsused to predict water content of cocoa powder ware1400-1450 nm and 1800-1950 $\mathrm{nm}$. The optimum best pretreatment method was found to be second Derivative.
\end{abstract}

Keywords: Water content, Cocoa Powder, Pretreatment, NIRS

\section{PENDAHULUAN}

Indonesia merupakan salah satu negara pembudidaya tanaman kakao yang luas didunia. Berdasarkan data ICCO (International Cocoa Organization) Indonesia merupakan urutan ke tiga dunia setelah Pantai Gading dan Ghana sebagai produsen biji kakao. Tahun 2014 produksi biji kakao Pantai Gading di perkirakan sebesar 1.746.000 ton, Ghana 897.000 ton dan Indonesia sebesar 375.000 ton. Permasalahan selama ini harga kakao Indonesia relative rendah dibandingkan Negara produsen lain. Faktor penyebab mutu kakao beragam yaitu minimnya sarana pengolahan, lemahnya pengawasan mutu serta kurangya penerapan teknologi pada tahapan proses pengolahannya. Kadar air pada kakao merupakan salah satu penyebabnya.Salah satu metode yang sedang berkembang dan digunakan untuk mendeteksi mutu suatu produk pertanian adalah metode pantulan infra merah dekat atau Near Infrared Reflectance Spectroscopy (NIRS). 
Menurut Spillane (1995) Kakao disebut juga dengan Theobroma cacao adalah sebutan nama biologi yang diberikan oleh Linnaeus pada tahun 1753. Tanaman kakao Indonesia yang banyak dibudidayakan diperkebunan rakyat adalah jenis forestero (lindak). Struktur buah kakao terdiri dari empat bagian yaitu kulit, plasenta, pulp, dan biji.Kakao memiliki standar mutu sebagai tolak ukur untuk pengawasan, salah satunya adalah kadar air biji kakaoyang ditentukan oleh cara pengeringan dan penyimpanannya. Industri pengolahan kakao membutuhkan biji kakao dengan kadar air antara 6 - $7 \%$. Jika lebih dari $8 \%$ resiko terserangnya hama dan bakteri lebih tinggi, akan tetapi jika kadar air kurang dari 5\%, kulit biji akan mudah pecah (Wahyudi dkk, 2008).

Menurut Strang (2004), NIRS merupakan teknik atau metode yang menggunakan radiasi sinar near infrared untuk menganalisis komposisi kimia dari 9 bahan organik. Informasi kandungan kimia ini didapatkan berdasarkan interaksi pantulan spektra dari bahan setelah diberi radiasi sinar near infrared.Kata spectroscopy seperti didefinisikan oleh Clark (1999) adalah studi tentang radiasi elektromagnetik sebagai fungsi dari panjang gelombang yang mana radiasi tersebut dapat berupa pantulan (reflectance), serapan (absorbance) dan terusan (transmittance) dari suatu bahan padat, cair atau gas.Bentuk spektrum dari radiasi near infrared ini yang kemudian digunakan untuk menganalisis dan memprediksi komposisi kimia bahan tersebut.

Teknik analisa data multivariasi pada NIRS dengan menggunakan kemometrika yang terdiri dari tiga aspek yaitu : Pengolahan data awal diantaranya (De-trending, Derivative ke-2), Model kalibrasi kuantitatif maupun kualitatif diantaranya (PCA,PLS), dan Transfer model.(Roggo et al., 2007).De-trending adalah Suatu metode yang cenderung untuk menghapus trend nonlinear dalam data spektroskopi. Sedangkan Derivative ke-2 digunakan untuk menghilangkan background dan meningkatkan resolusi spektrumCen and He (2007).PLS (Partial Least Square)adalahsebuah metode reduksi dimensi data untuk mencari faktor faktor yang paling relevan dalam memprediksi dan menginterpretasi data.

\section{METODE PENELITIAN}

Penelitian dilaksanakan pada bulan Februari sampai April 2016 dilakukan di Laboratorium Instrumentasi dan Energi, Program Studi Teknik Pertanian, Fakultas Pertanian, Universitas Syiah Kuala, Banda Aceh.

\section{Alat dan Bahan}

Alat yang digunakan adalah adalah FT-IR IPTEK T-1516, perlengkapan pembubukan biji kakao, perlengkapan uji kadar air, dan unscrambler software ${ }^{\circledR} X$ version 10.1 . Bahan yang digunakan adalah biji kakao.

\section{Persiapan Sampel Bubuk Biji Kakao}

Penelitian ini menggunakan buah kakao varietas Lindak yang didapat dari Jember.Kemudian kakao tersebut disimpan selama 3 hari di ruangan dengan suhu $25{ }^{\circ} \mathrm{C}$ yang bertujuan untuk menstabilkan suhu pada biji kakao.Selanjutnya biji kakao diblender untuk memperoleh bubuk kasar. Selanjutnya diayak dengan ayakan berukuran 24 mesh untuk mendapatkan bubuk kakao yang halus. Selanjutnya sampel dibagi menjadi 30 sampel dengan 2 tingkat fermentasi yaitu 0 hari (F0) dan 5 hari (F5) dengan berat persampel sebesar 10 gr.kemudian dilakukan proses pengambilan spektrum menggunakan NIRS dan pengukuran kadar air dengan metode thermogravimetri. 


\section{Pengambilan Spektrum Bubuk Biji Kakao}

Terlebih dahulu dilakukan kalibrasi background/reference pada alat adalah FT-IR IPTEK T-1516 tiap jam. Proses bekerjanya alat menggunakan integrating sphere. Digunakan software termointegration ${ }^{\circledR}$ untuk pengendalian kerja alat untuk pembuatan workflow dan menjalankan workflow, untuk running alat dilakukan oleh termo operation ${ }^{\circledR}$.Selang gelombang yang dipilih adalah antara 1000-2500 $\mathrm{nm}$ dengan interval $0.4 \mathrm{~nm}$. Workflowdibuat untuk mengatur alat agar bekerja untuk mengakuisisi spektrum absorban, memindai sampel sebanyak 64 kali perproses lalu dirata-ratakan hasilnya, kemudian disimpan hasil pemindaian dalam 3 bentuk file yakni *.SPA. *.JDX dan *.CSV. Akuisisi spektrum bubuk biji kakao dengan pengambilan spektrumnya yaitu memasukkan bubuk biji kakao ke dalam petridish yang tersedia lalu diputar 360 derajat selama proses pemindaian sampel. Pengolah data spektrum menggunakan unscrambler software ${ }^{\circledR} X$ version 10.1. Pretreatment yang digunakan adalah De-trending dan Derivative ke-2.

\section{Pengukuran Kadar Air Bubuk Biji Kakao}

Pengujian kadar air menggunakan adalah metode thermogravimetri. Prosedur pengukuran adalah cawan keramik kosong dikeringkan dalam oven dengan suhu $105^{\circ} \mathrm{C}$ selama 15 menit dan didinginkan dalam exicator selama 10 menit, kemudian ditimbang.Sampel yang sudah diambil data spektranya ditimbang 10 gram kemudian dimasukkan ke dalam cawan.Cawan beserta isinya kemudian dimasukkan ke dalam oven dengan suhu $105^{\circ} \mathrm{C}$ selama 6 jam.Selanjutnya cawan dikeluarkan dari oven dan didinginkan kembali dalam exicator dan ditimbang kembali. Perhitungan kadar air (KA) menggunakan persamaan :

$$
\mathrm{KA}(\% \text { basis basah })=\frac{\text { Berat awal }- \text { Berat akhir }}{\text { Berat awal }} \times 100 \% \text {. }
$$

\section{Pengembangan dan Pengujian Model Kalibrasi}

Model prediksi dibangun dengan menggunakan metode Partial Least Squares (PLS) yang dibandingkan dengan hasil uji laboratorium. Tipe validasi silang yang di gunakan adalah $K$-fold cross validation dengan jumlah segment (fold) adalah 10. Evaluasi keakuratan dan kehandalan model kalibrasi dalam menentukan kadar air pada bubuk biji kakao dievaluasi dengan melihat parameter statistik yang meliputi: $\mathrm{R}^{2}$, koefisien kolerasi (r), residual predictive deviation (RPD) index, root mean square error cross validation (RMSECV), root mean square error calibration (RMSEC).Model persamaan kalibrasi data serapan dibandingkan dengan data aktual dan dilihat nilai $\mathrm{R}^{2}$, r, RMSEC, RMSECV, RPD, dan dRMSE. Model yang bagus memiliki nilai ${ }^{2}$, $r$ yang tinggi, RMSEC yang rendah, RPD $\geq 1.5$,RMSEC dan RPD dicari dengan persamaan (Florez, 2009 ; Jha, 2006 ; Nicolai, 2007) :

$$
\begin{gathered}
R M S E C, R M S E C V=\sqrt{\frac{1}{n} \sum_{i=1}^{n}\left(\hat{y}_{i}-y_{i}\right)} \\
R P D=\frac{S D}{R M S E C V} \ldots \ldots \ldots \ldots \ldots \ldots \ldots \ldots \ldots \ldots \ldots \ldots \ldots \ldots
\end{gathered}
$$

\section{HASIL DAN PEMBAHASAN}

\section{Tipikal Spektrum}

Spektrum bubuk biji kakao menampilkan adanya puncak-puncak gelombang yang mewakili keberadaan ikatan kimia tertentu. Puncak-puncak itu muncul akibat vibrasi (getaran atom dalam molekul) pada kelompok ikatan atom seperti O-H, N-H, dan C-H.Spektrum awal bubuk biji kakao telah memberikan informasi akan adanya kandungan kimia seperti kadar air,

Komparasi Metode Koreksi Spektrum NIRS (De-Trending dan Derivatif ke-2) untuk Penentuan Kadar 
kadar lemak dari kakao bubuk. Hal ini serupa dengan pernyataan dari Strang (2004) NIR mampu menganalisis komposisi kimia.

Spektrum awal bubuk biji kakao (Non pretreatment) terlihat adanya tingkat pantulan yang berbeda beda sehingga memunculkan lembah dan puncak. Semakin besar komposisi kimia suatu bahan, maka penyerapan akan semakin besar dan juga puncak gelombang semakin tinggi. Munculnya lembah dan puncak pada spektrum di akibatkan karena adanya transreflectance yang tumpang tindih. Proses pembubukan telah membuat partikel kakao menjadi seragam sehingga gangguan dalam pemindaian sudah cukup teratasi. Akan tetapi pembubukan telah membuat kandungan air dari bubuk biji kakao menjadi berkurang sehingga keberadaan kadar air menjadi tidak begitu jelas dibandingkan kandungan kimia dari lemak seperti yang terlihat pada Gambar 1.

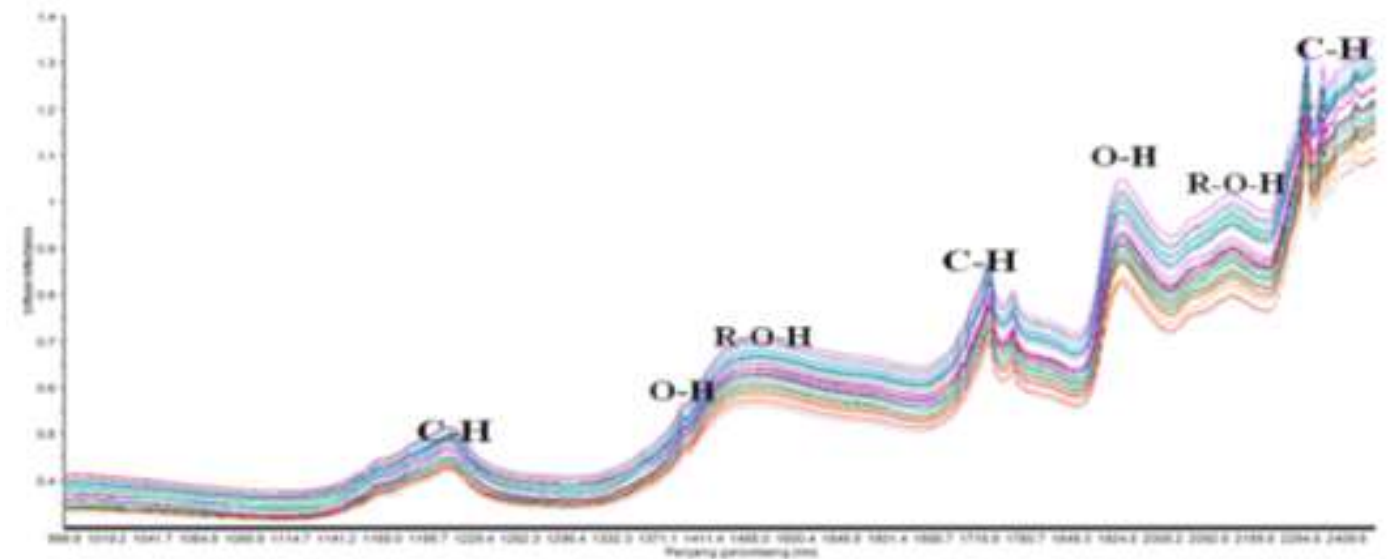

Gambar 1. Spektrum Awal Bubuk Biji Kakao

Salah satu kandungan kimia yang terlihat pada penelitian ini adalah kandungan air pada panjang gelombang gelombang 1400-1455 nm dan 1900-1950 nm. Serupa dengan penelitian Zulfahrizal (2014) yang mana informasi kandungan air berada pada panjang gelombang 1400$1480 \mathrm{~nm}$ dan 1900-2000 nm. Puncak kadar air pertama pada panjang gelombang 1400-1455 $\mathrm{nm}$ dan kedua pada panjang gelombang 1900-1950 nm tergolong kedalam jenis second overton (overton ke-2). Kedua puncak tersebut dapat dikatakan panjang gelombang relevan untuk mendeteksi kandungan air pada bubuk biji kakao.

\section{Koreksi Spektrum}

Penggunaan pretreatment bertujuan untuk mengurangi pengaruh interferensi gelombang noise yang menyebabkan kumpulan spektrum bubuk biji kakao lebih halus dan lebih rapat.Penambahan pretreatment De-Trending telah mampu menghapus trend nonlinear pada data spektrum. Kandungan air pada pretreatment De-trending telihat pada panjang gelombang 1390-1400 nm dan 1870-1950 nm seperti yang terlihat pada Gambar 2. Kedua puncak tersebut masih sama tergolong puncak relevan untuk mendeteksi kadar air pada bubuk biji kakao. 


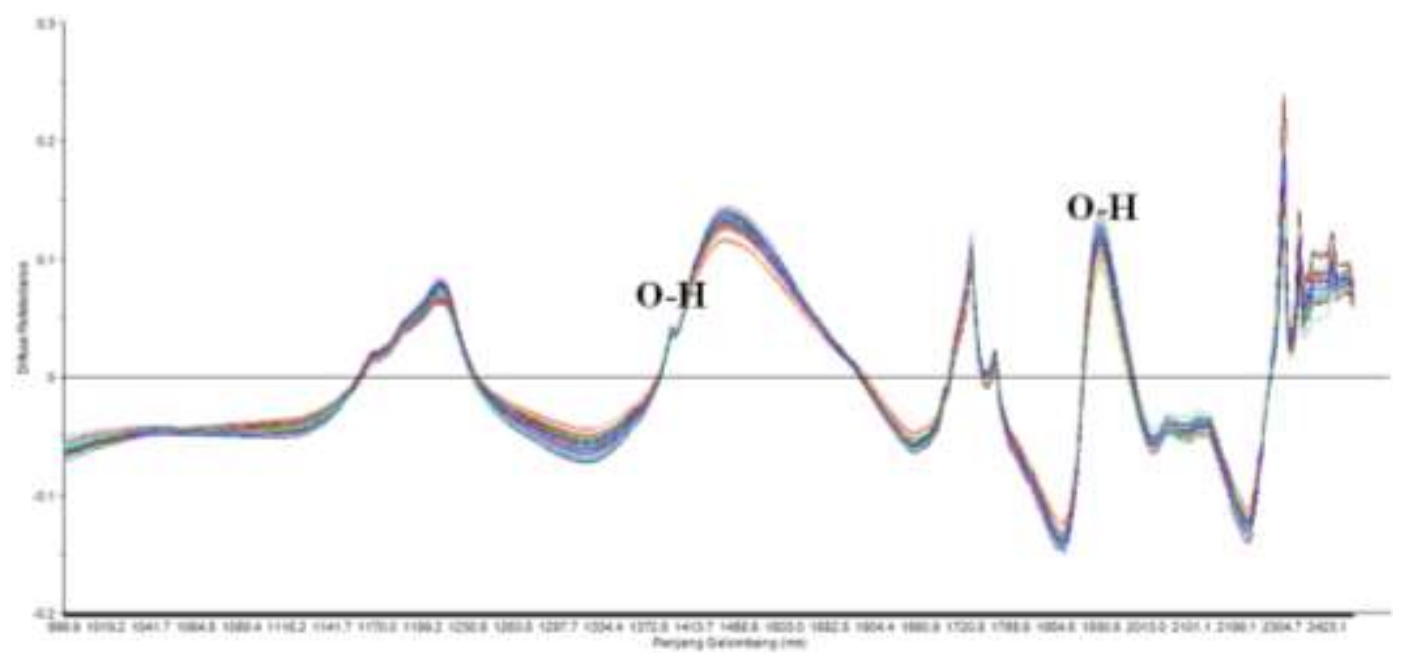

Gambar 2. Spektrum Bubuk Biji Kakao+ Pretreatment De-Trending

Pretreatment Derivative ke-2 digunakan untuk menghilangkan background dan meningkatkan resolusi spektrum.Penggunaan pretreatment Derivative ke-2 telah berhasil menghilangkan baseline dan mempertajam perbedaan spektrum sehingga serapan spektrum tidak saling tumpang tindih maka pola spektranya terlihat lebih jelas namun puncaknya lebih sedikit seperti yang terlihat pada Gambar 3.Salah satu kandungan kimia yang telihat adalah kadar air yaitu pada panjang gelombang 1380-1400 nm dan 1880-1900 nm. Panjang gelombang relevan pada pretreatment Derivative ke-2 adalah 1380-1400 nm dan 1880-1900 nm.

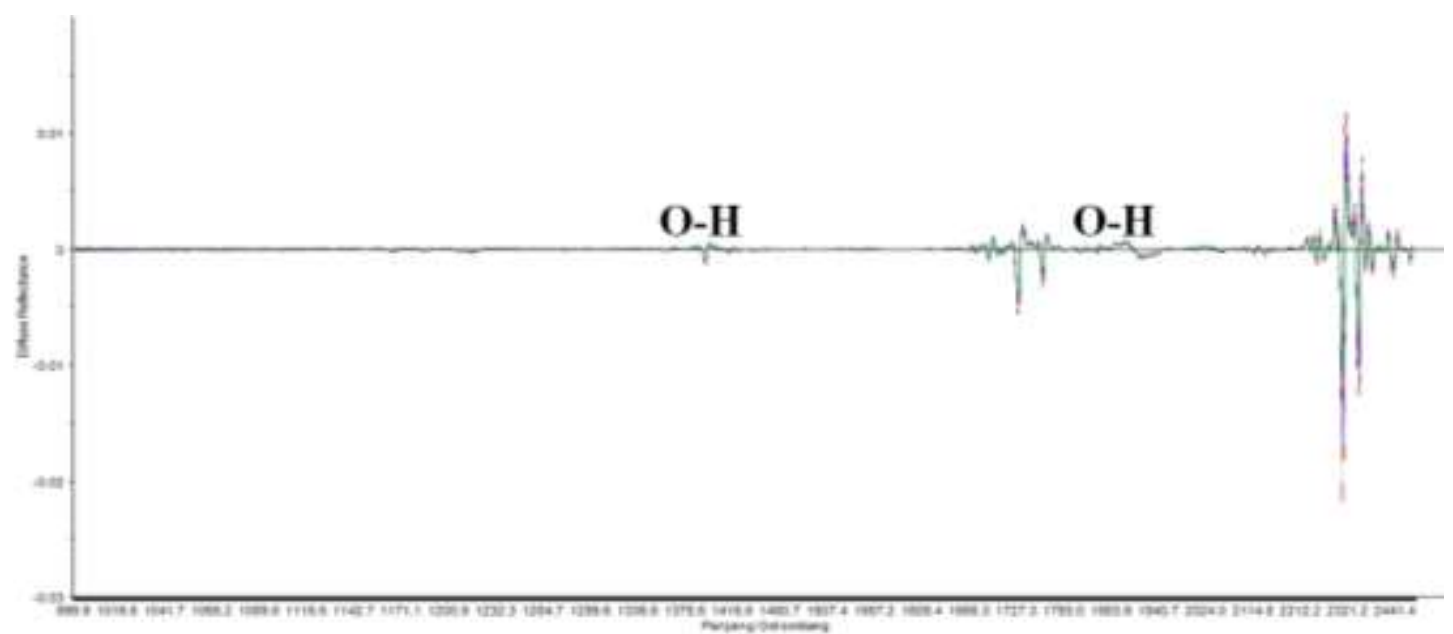

Gambar 3. Spektrum Bubuk Biji Kakao + Pretreatment Derivative ke-2

\section{Pengembangan Model Kalibrasi (PLS)}

Tujuan kalibrasi adalah untuk membangun model persamaan matematik. Proses kalibrasi menggunakan 30 sampel bubuk biji kakao.

Tabel 1. Acuan Pengukuran Data Kalibrasi

\begin{tabular}{lcccc}
\hline Bagian & $\begin{array}{c}\text { Jumlah } \\
\text { data }\end{array}$ & Selang $(\%)$ & Rataan & Standar Deviasi \\
\hline Kalibrasi & 30 & $7.42-11.09$ & 8.857 & 0.9353 \\
\hline
\end{tabular}

Komparasi Metode Koreksi Spektrum NIRS (De-Trending dan Derivatif ke-2) untuk Penentuan Kadar 
Hasil dari kalibrasi dapat digunakan untuk memprediksi kandungan kimia biji kakao tanpa harus melakukan pengukuran langsung secara destruktif atau merusak bahan. Data hasil analisa kalibrasi PLS untuk uji kadar air menggunakan NIRS pada bubuk biji kakao dapat dilihat pada Tabel 2.

Tabel 2.Data Hasil Pengukuran Kalibrasi

\begin{tabular}{lcccc}
\hline Perlakuan & Latent variable $(\boldsymbol{\%})$ & $\mathbf{R}^{\mathbf{2}}$ & $\mathbf{r}$ & RMSEC \\
\hline Non pretreatment & 3 & 0.75 & 0.87 & 0.45 \\
De - Trending & 3 & 0.70 & 0.84 & 0.49 \\
Derivatif ke-2 & 4 & 0.92 & 0.95 & 0.25 \\
\hline
\end{tabular}

Berdasarkan data hasil kalibrasi pada pendugaan kadar air bubuk biji kakao non pretreatment dan pretreatment diperoleh hasil berbeda - beda. Perlakuan non pretreatment diperoleh nilai $\mathrm{R}^{2}$ yang mendekati prediksi kuantitatif yaitu sebesar 0.75 karena menurut Karoi (2006) nilai 0.66-0.81 tergolong mendekati prediksi kuantitatif.Sedangkan nilai $\mathrm{r}$ didapat sebesar 0.87. Jika dilihat dari nilai error atau RMSEC masih tergolong rendah yaitu sebesar 0.45 dapat dilihat pada Gambar 4.

Pretreatment De-Trending memiliki nilai $\mathrm{R}^{2}$ yaitu sebesar 0.70 yang mendekati prediksi kuantitatif karena menurut Karoui (2006) nilai koefisien determinasi 0.66-0.81 tergolong mendekati prediksi kuantitatif. Selain itu nilai $\mathrm{r}$ didapat sebesar 0.84.Jika dilihat dari nilai errornya diperoleh sebesar 0.49 , perolehan nilai error demikian masih dikatakan bagus karena berada di bawah nilai standar deviasi seperti pada Gambar 5.

Pretreatment Derivative $k e-2$ memiliki nilai $\mathrm{R}^{2}$ sebesar 0.92 yang merupakan peningkatan yang begitu besar seperti pada Gambar 4.10.Perolehan nilai demikian merupakan pendugaan yang baik karena Menurut Karoui et al. (2005) nilai $\mathrm{R}^{2}$ antara $0.82-0.90$ menyatakan dugaan baik. Perolehan nilai r pada pretreatment ini tergolong tinggi yaitu sebesar 0.95 seperti pada Gambar 6, menurut Wiliam dan Norris (1990) nilai $\mathrm{r}$ di atas 0.90 atau mendekati 1 sudah dikatakan tinggi. Selanjutnya nilai error didapat yaitu sebesar 0.25 lebih kecil dari nilai standar deviasi data sehingga dapat dikatakan bagus.

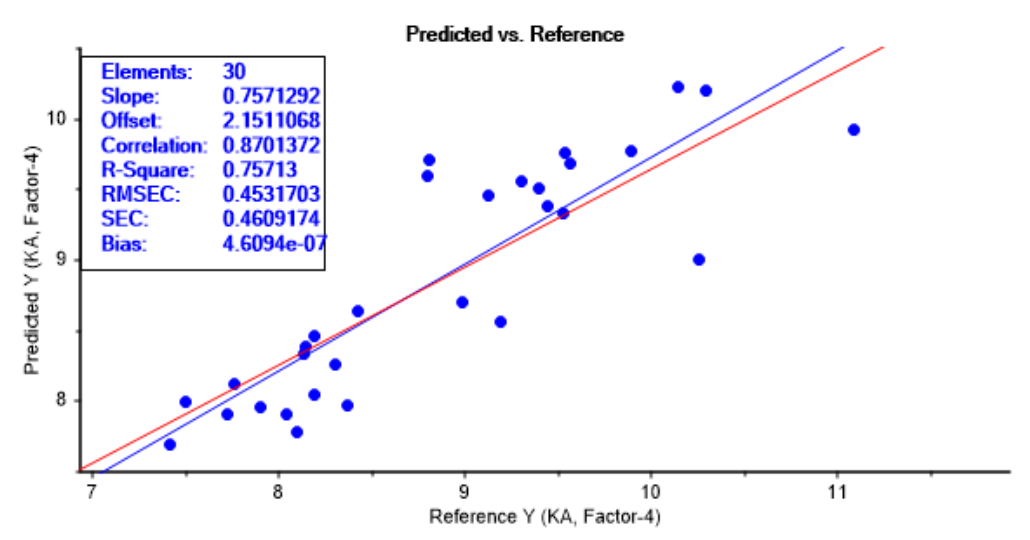

Gambar 4. Plot Data Kalibrasi Kadar Air Non Pretreatment

Komparasi Metode Koreksi Spektrum NIRS (De-Trending dan Derivatif ke-2) untuk Penentuan Kadar Air Bubuk Biji kakao 


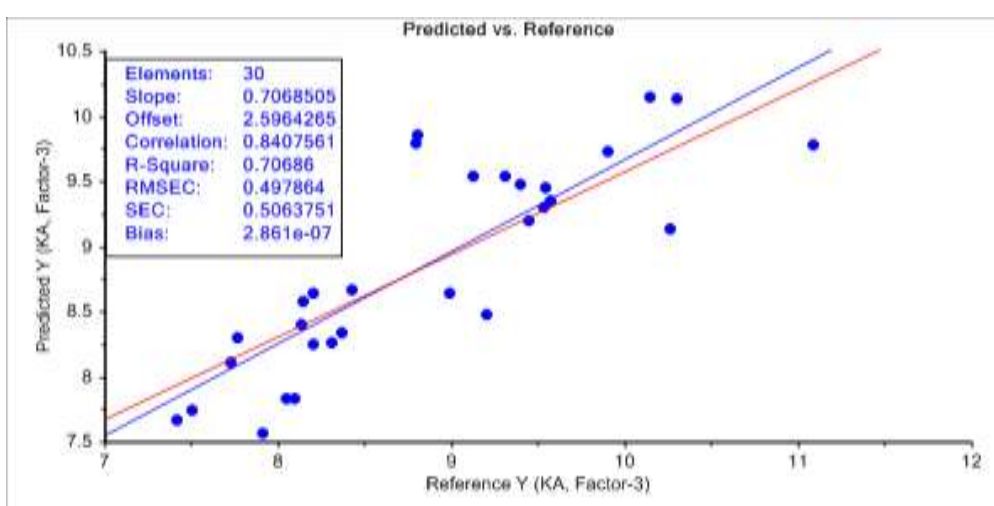

Gambar 5. Plot Data Kalibrasi Kadar air PretreatmentDe-Trending

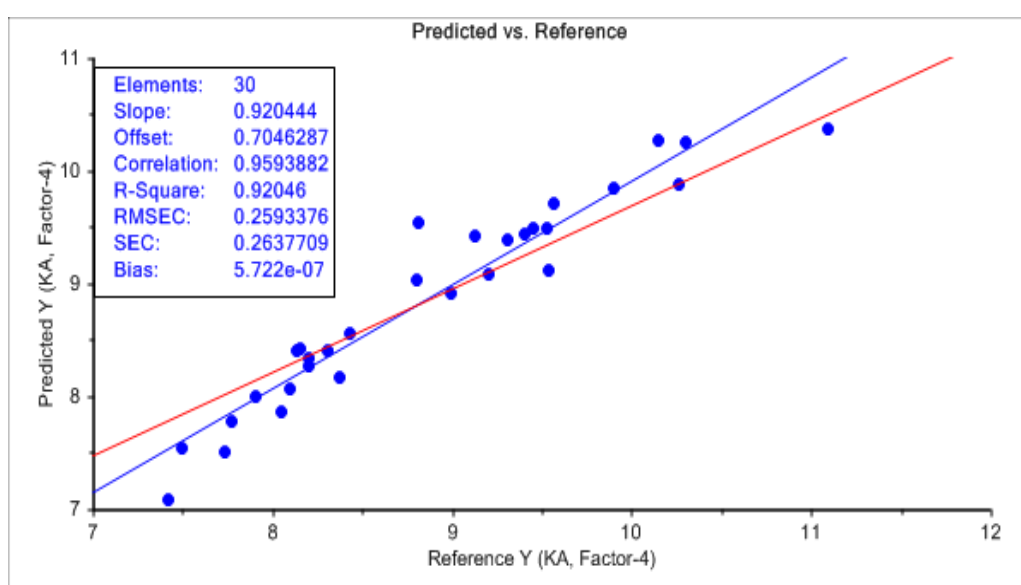

Gambar 6. Plot Data Kalibrasi Kadar air Pretreatment Derivatif ke-2

\section{Pengujian Model (K-fold Cross Validation)}

Tujuan dilakukan cross validation adalah untuk menilai/ memvalidasi keakuratan sebuah model yang dibangun berdasarkan dataset tertentu.Pada penelitian ini jumlah sampel yang digunakan adalah 30 sampel.Adapun data hasil pengukuran cros validasi untuk beberapa perlakuan dapat dilihat pada Tabel 3.

Tabel 3. Data Hasil Pengukuran Cros Validasi

\begin{tabular}{lccccc}
\hline Perlakuan & $\mathbf{R}^{\mathbf{2}}$ & $\mathbf{r}$ & RMSECV & dRMSE (\%) & RPD \\
\hline Non pretreatment & 0.67 & 0.80 & 0.54 & 0.09 & 1.73 \\
De - Trending & 0.63 & 0.78 & 0.57 & 0.08 & 1.62 \\
Derivatif-2 & 0.75 & 0.85 & 0.47 & 0.22 & 1.98 \\
\hline
\end{tabular}

Keakuratan model kalibrasi ditentukan berdasarkan nilai $\mathrm{R}^{2}$, r, error, delta error, dan RPD. Pada Gambar 7 perlakuan non pretreatment nilai $\mathrm{R}^{2}$ yang didapat adalah 0.67 . Menurut Karoui et al. (2006), nilai $\mathrm{R}^{2}$ berkisar 0,66 dan 0,81 mendekati prediksi kuantitatif. Sedangkan nilai $\mathrm{r}$ yang didapat cukup besar yakni 0.80, untuk nilai error (RMSECV) yang didapat masih dikatakan baik karena masih di bawah nilai SD data.Selanjutnya jika dilihat dari nilai RPD, ternyata didapat sebesar 1.73.Menurut Nicolai et al. (2007) nilai RPD yang berada dalam selang 1.5 - 2 menandakan bahwa model itu termasuk sufficient performance yang dapat dikatakan mendekati prediksi kuantitatif kasar yang dianggap mungkin.

Pemakaian pretreatment De-trending tidak meningkatkan kinerja PLS seperti yang terlihat pada Pada Gambar 8.Hal ini bisa dilihat dari nilai koefisien korelasi (r) yang semakin

Komparasi Metode Koreksi Spektrum NIRS (De-Trending dan Derivatif ke-2) untuk Penentuan Kadar Air Bubuk Biji kakao 
menurun menjadi 0.78 dan nilai koefisien determinasi $\left(\mathrm{R}^{2}\right)$ juga menurun menjadi 0.63.Selain itu nilai error (RMSECV) juga semakin meningkat menjadi 0.57. Selanjutnya jika dilihat dari nilai RPD pretreatment ini menghasilkan nilai yaitu 1.62, namun tetap masih tergolong kedalam sufficient performance karena berada pada selang 1.5 - 2 .

Penggunaan pretreatment Derivative ke-2 telah meningkatkan kinerja PLS non dilihat dari nilai $\mathrm{R}^{2}$ menjadi 0.75 dan $\mathrm{r}$ menjadi 0.85 . Walaupun nilai tersebut masih sama-sama tergolong mendekati prediksi kuantitatif. Petreatment Derivative ke-2 juga telah menurunkan nilai error (RMSECV) yaitu menjadi 0.47 seperti pada Gambar 9. Berarti penggunaan pretreatment Derivative ke-2 cukup bagus dalam mengurangi nilai error karena semakin sedikit nilai error semakin bagus. Sedangkan jika dilihat dari nilai RPD mengalami peningkatan tetapi tetap masih tergolong kedalam sufficient performance.

Jadi berdasarkan penguraian diatas dapat disimpulkan bahwa model pendugaan yang paling bagus adalah PLS dengan pretreatment Derivatif $k e-2$. Penyebabnya karena nilai $\mathrm{R}^{2}, \mathrm{r}$ dan RPD paling tinggi serta nilai error paling sedikit.

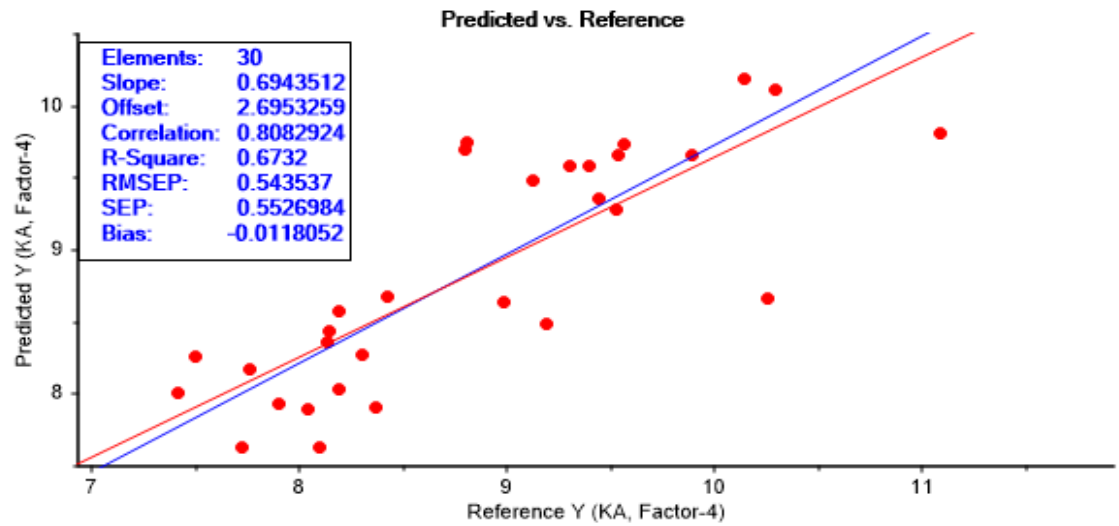

Gambar 7. Plot Data Validasi Kadar Air Non Pretreatment

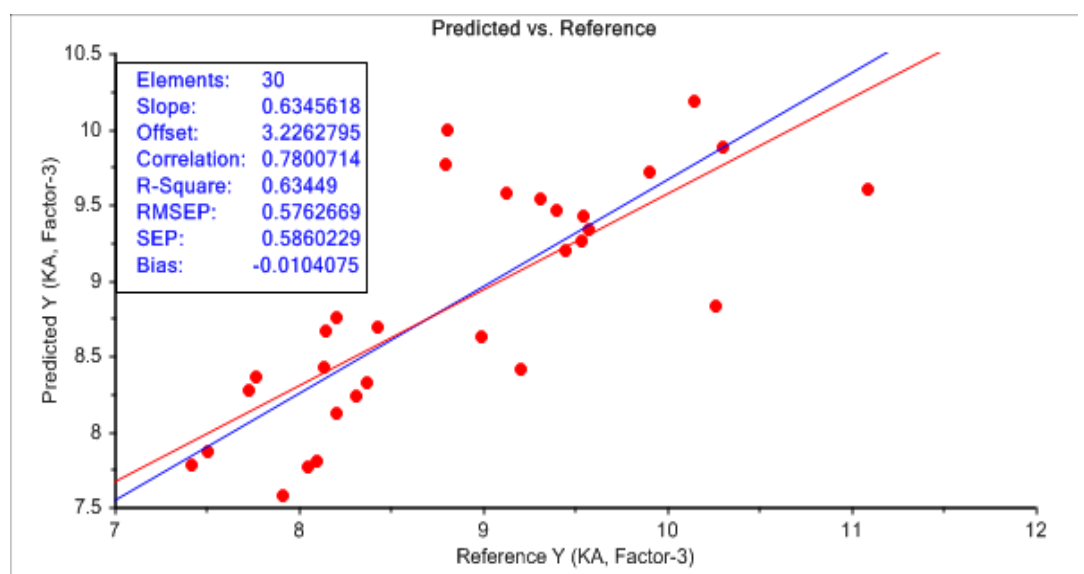

Gambar 8. Plot Data Validasi Kadar air Pretreatment Detrending 


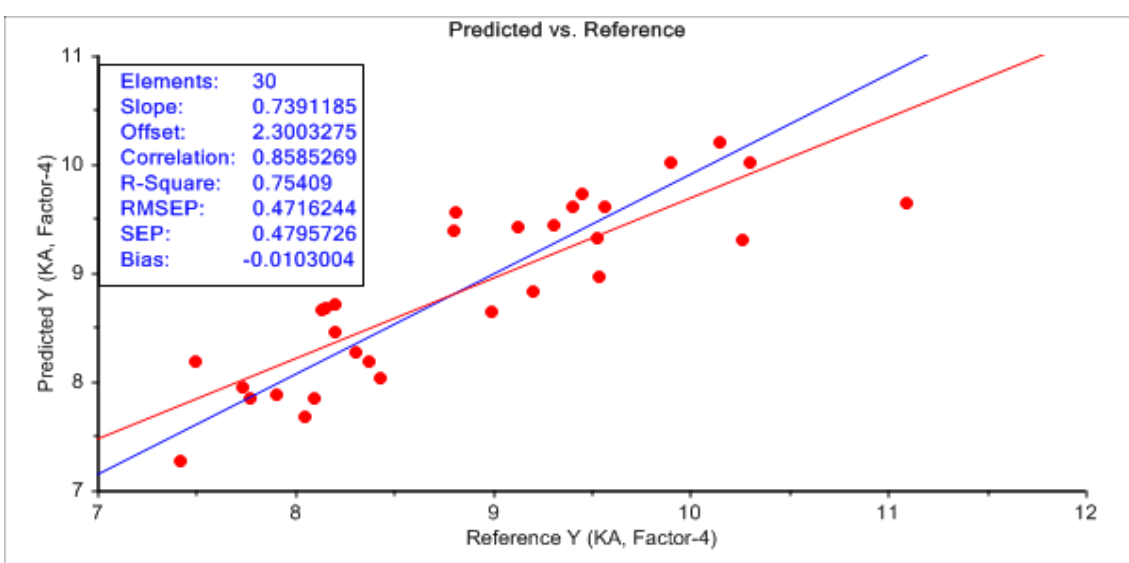

Gambar 9. Plot Data Validasi Kadar air Pretreatment Derivatif ke-2

\section{KESIMPULAN DAN SARAN}

Berdasarkan penelitian maka kesimpulannya adalah panjang gelombang relevan dalam menduga kadar air pada bubuk biji kakao adalah 1400-1450 nm dan 1800-1950 nm. Peningkatkan kinerja PLS yang paling bagus adalah menggunakan pretreatment derivative ke2 karena menghasilkan nilai $\mathrm{R}^{2}$ sebesar 0.75 , nilai (r) sebesar 0.85 , nilai error sebesar 0.47 dan nilai RPD sebesar 1.96 yang tergolong sufficient performance. Pendugaan kadar air dalam jumlah 10 gram dengan selang kadar air 7.42 - 11.09 mampu diprediksi dengan metode NIR menggunakan PLS secara non pretreatment maupun pretreatment.

Sedangkan saranny adalah Perlu dilakukan penelitian lebih lanjut dengan melakukan penambahan beberapa pretreatment lain dan penambahan metode regresi lain baik secara linear dan non linear.

\section{DAFTAR PUSTAKA}

Cen, H., He, Y. 2007. Theory and application of nea inrfrared reflectance spectroscopy in determination of food quality. J. Trends in food sci \& technol 18: 72-83.

Clark, R.N. 1999. Spectroscopy of rocks and minerals and principles of spectroscopy. In: ed. Rencz. AN. Manual of Remote Sensing. Volume 3: Remote Sensing for the Earth Sciences. ch.1. New York (USA): John Wiley and Sons. p 3-58

International Cocoa Organization. 2015. ICCO Quarterly of Cocoa Statistic.http//www.icco.org/[28 Agustus 2015]

Karoui R., A. M. Mouazena, E. Dufourb, L. Pillonelc, E. Schallerd, J. De Baerdemaekera, Dan J. O. Bossetc. 2006. Chemical Characterisation Of European Emmental Cheeses By Near Infrared Spectroscopy Using Chemometric Tools. International Dairy Journal. 16: 1211-1217.

Nicolai, B. M., K. Beullens, E. Bobelyn, A.Peirs, W.Saeys, K. I.Theron, J.Lamertyn. 2007. Nondestructive Measurement of Fruit and Vegetable Quality by Means of NIR Spectroscopy: A Review. Postharvest Biology and Technology. 46: 99-118.

Roggo Y., Chalus P., Maurer L., Martinez C.M., Edmond A., Jent N. 2007.A review of near infrared spectroscopy and chemometrics in pharmaceutical technologies. Journal of Pharmaceutical and Biomedical Analysis 44: 683-700.

Komparasi Metode Koreksi Spektrum NIRS (De-Trending dan Derivatif ke-2) untuk Penentuan Kadar 
Spillane, J. J. 1995. Komoditi Kakao Peranannya Dalam Perekonomian Indonesia. Kanius, Yogyakarta.

Strang, G. C. 2004. Near infrared reflectance spectroscopy and its specific applications in livestock agriculture.School of bioresources engineering and environmental hydrology. Pietermaritzburg: University of Kwazulu-Natal,Pietermaritzburg.

Wahyudi, T., T.R Pangabean., dan Pujianto. 2008. Panduan Lengkap Kakao Manajemen Agribisnis Dari Hulu Hingga Hilir. Penebar Swadaya, Jakarta.

William, P dan Norris,K. 1990. Near infrared technology in the agricultural and foodindustries.American Association of Cereal Chemiist, Inc, St. Paul. USA.

Zulfahrizal. 2014. Pengembangan metode pengukuran nondestruktif untuk menentukan mutu dan fermentasi biji kakao utuh menggunakan nir spectroscopy. Disertasi. Institut Pertanian Bogor .Bogor . 